\title{
Studies on compatibility and profitability of intercrops in turmeric
}

\author{
P. Hemalatha* and R. Chitra \\ Agricultural Research Station (T.N.A.U.), Bhavanisagar, Erode D.T. (T.N.) India \\ (Email : hemahort@yahoo.com)
}

\begin{abstract}
Turmeric occupies about 6 per cent of the total area under spices and condiments in India. It is a long duration crop and the initial growth of turmeric is rather slow and takes about 4-5 months to cover the interspace. Therefore, the available space between the rows of turmeric could be effectively utilized by growing short duration crops like, vegetables, cereals etc. Hence, it is worthwhile to explore the possibilities of growing compatible crops with turmeric. With this background, this research project was formulated to find out the best compatible intercrop with turmeric, to study the effect of intercrops on growth and yield of turmeric and to determine the economic feasibility of turmeric based intercropping. In a nutshell, taking into consideration of the performance of various treatments in this experiment, it can be concluded that growing onion as an intercrop was found to be the best with respect to turmeric growth characters like plant height, number of leaves per plant, leaf length and leaf breadth. Although intercropping turmeric with cowpea is found compatible with maximum fresh turmeric rhizome yield per hectare (31.03 $\mathrm{t} / \mathrm{ha}$ ), the maximum B : C ration (2.53:1) was registered by turmeric intercropped with okra followed by turmeric + chilli (2.51:1). The monocropping of turmeric recorded the lowest $\mathrm{B}: \mathrm{C}$ ration (1.70:1) among all the treatments.
\end{abstract}

Key Words : Intercrops, Turmeric, Compatibility, Equivalent yield, Benefit cost ratio

View Point Article : Hemalatha, P. and Chitra, R. (2018). Studies on compatibility and profitability of intercrops in turmeric. Internat. J. agric. Sci., 14 (2) : 308-312, DOI:10.15740/HAS/IJAS/14.2/308-312. Copyright@ 2018: Hind Agri-Horticultural Society.

Article History : Received : 07.03.2018; Revised : 20.04.2018; Accepted : 06.05.2018

\footnotetext{
* Author for correspondence:
} 